\title{
FAKTOR-FAKTOR YANG MEMENGARUHI KESETIAAN TENAGA KERJA GENERASI Y
}

\author{
Billy Chandra ${ }^{1}$, Edi Purwanto ${ }^{2}$ \\ ${ }^{I}$ Magister Manajemen, Universitas Bunda Mulia, Jakarta \\ ${ }^{2}$ Magister Manajemen, Universitas Bunda Mulia, Jakarta
}

\begin{abstract}
ABSTRAK:
Penelitian ini dilakukan untuk mengetahui faktor-faktor apa saja yang memengaruhi kesetiaan tenaga kerja generasi $\mathrm{Y}$ yang bekerja sebagai karyawan tetap atau permanen dan bekerja di wilayah Jabodetabek. Banyak tenaga kerja generasi Y yang dilihat tidak memiliki kesetiaan seperti generasi sebelumnya yang dapat bekerja sangat lama di suatu perusahaan. Peneliti tertarik untuk menggali faktor-faktor apa yang dapat memicu timbulnya kesetiaan tersebut muncul pada generasi Y. Secara sekilas peneliti melihat faktor kualitas kehidupan kerja dan kinerja yang berpengaruh terhadap kesetiaan tenaga kerja generasi $\mathrm{Y}$ tersebut. Pada penelitian ini model yang digunakan adalah model penelitian kuantitatif yang berfungsi untuk melihat apakah adanya hubungan yang positif dan signifikan antara peubah yang memengaruhi kesetiaan tenaga kerja generasi Y, sepeerti kualtias kehidupan kerja dan kinerja. Data yang digunakan pada penelitian ini merupakan data primer yang didapat secara langsung melalui kuesioner yang disebarkan, serta penelusuran pustaka melalui jurnal sebagai data sekunder, untuk mencari, membandingkan dan menelaah peubah-peubah seperti apa yang berpengaruh positif dan dapat memengaruhi kualitas kehidupan kerja dan kinerja sehingga tercipta kesetiaan. Selama penelitian ini dilakukan, peneliti menemukan beberapa peubah yang diduga dapat meningkatkan kesetiaan tenaga kerja generasi Y selain kualitas kehidupan kerja dan kinerja, diantaranya kompensasi, pengembangan karier dan dukungan sosial yang berpengaruh secara simultan terhadap penelitian ini.
\end{abstract}

Kata Kunci: Kesetiaan, Tenaga Kerja, Generasi Y

\section{ABSTRACT:}

This research was conducted to find out what factors influenced the loyalty of Gen $Y$ labor who worked as permanent employees and worked in Jabodetabek area. Many of the Gen Y workforce seen haven't loyal like the previous generation that can work very long in a company. Researcher are interested to explore what factors can trigger the emergence of loyalty to appears in Gen Y. At a glance researcher consider the quality of work and job performance factors are affect the loyalty of the Gen Y labor. In this study the model used is a quantitative research model that serves to see whether there is a positive and significant relationship between the variables that affect the loyalty of Gen $Y$ labor, such as the quality of work life and job performance. The data used in this study are primary data obtained directly through distributed questionnaires, as well as library search through journals as secondary data, to compare and examine what variables are positively affected and can affect the quality of work life and job performance so that can create loyalty.During the research, the researcher found that 


\section{National Conference of Creative Industry: \\ Sustainable Tourism Industry for Economic Development}

Universitas Bunda Mulia, Jakarta, 5-6 September 2018 e-ISSN No: 2622-7436

some variables were allegedly able to increase the loyalty of the Gen Y labor in addition to quality of work life and performance, including compensation, career development and social support that simultaneously affected this research.

Keywords: Loyalty, Employee, Gen Y

\section{PENDAHULUAN}

Pentingnya kesetiaan atau loyalitas di tempat kerja telah diakui di seluruh dunia karena kinerja setiap organisasi bergantung pada kesetiaan pegawainya; Semakin banyak karyawan yang setia, semakin baik kinerja organisasi tersebut (Ibrahim \& Al Falasi, 2014). Pada kenyataannya, kesetiaan dianggap sebagai faktor kunci yang menentukan keberhasilan organisasi dalam bisnis modern saat ini, yang kita ketahui semakin meningkatnya persaingan dan kemajuan teknologi. Dalam keadaan semacam itu, organisasi perlu menarik dan mempertahankan sumber daya manusia yang terampil, andal dan setia untuk mempertahankan daya saingnya di pasar (Ibrahim \& Al Falasi, 2014). Kesetiaan juga dianggap sebagai kunci kualitas dan peningkatan produktivitas (Ibrahim \& Al Falasi, 2014). Organisasi telah menginvestasikan sejumlah besar sumber daya serta upaya untuk menarik, merekrut dan mempertahankan karyawan yang proaktif, terlibat dan berkomitmen (Ibrahim \& Al Falasi, 2014). Menurut Clarke (2015) Generasi Y (Gen Y) atau mereka yang lahir antara tahun 1980 dan 2000. Memiliki tiga karakterisitik. Pertama, Gen Y telah dididik dalam lingkungan di mana mereka telah didorong untuk mengejar keberhasilan tanpa memandang jender atau status dan di mana adanya harapan kesetaraan gender (Clarke, 2015). Kedua, mereka cenderung dipekerjakan dalam peran yang menuntut ketidakseimbangan antara keluarga dan kerja, dan dihadapkan pada masalah bagaimana mengelola karier ganda serta kepentingan dan tanggung jawab non-kerja (Clarke, 2015). Sementara banyak karier pada tingkat profesional yang menuntut jam kerja yang lebih panjang. Ketiga, ada beberapa bukti yang membedakan Gen $\mathrm{Y}$ dan generasi sebelumnya dalam hal nilai kerja dan aspirasi karir (Clarke, 2015). Sejumlah penelitian telah menunjukkan bahwa Gen Y mencari keseimbangan kehidupan kerja yang jauh lebih baik daripada orangtua mereka, generasi Baby Boomer (Clarke, 2015) dan mereka bertekad untuk menjadikan ini prioritas. Berangkat dari fenomena tersebut, ditemukan beberapa hal serupa seperti yang diuraikan pada penelusuran pustaka sebelumnya. Sebagian mempertanyakan apakah terdapat kesetiaan seperti yang disampaikan sebelumnya. Sejumlah tenaga kerja tertentu dapat setia dan bahkan telah menghabiskan waktu yang cukup lama bekerja di satu perusahaan, mereka umumnya sudah merasa nyaman dengan budaya, lingkungan sosial dan kehidupan kerja di perusahaan tersebut. Namun terdapat juga tenaga kerja yang bertolak belakang, tenaga kerja yang dengan mudah dapat melayangkan surat pengunduran diri. Muncul sebuah pemikiran, mungkinkah tenaga kerja generasi $\mathrm{Y}$ tersebut tidak mampu menyesuaikan diri dengan kondisi kerja mereka atau pada dasarnya mereka memang memiliki kesetiaan yang buruk? Berdasarkan data angkatan kerja yang dimiliki oleh Badan Pusat Statistik (BPS), kita dapat melihat beberapa hal seperti berikut ini. 


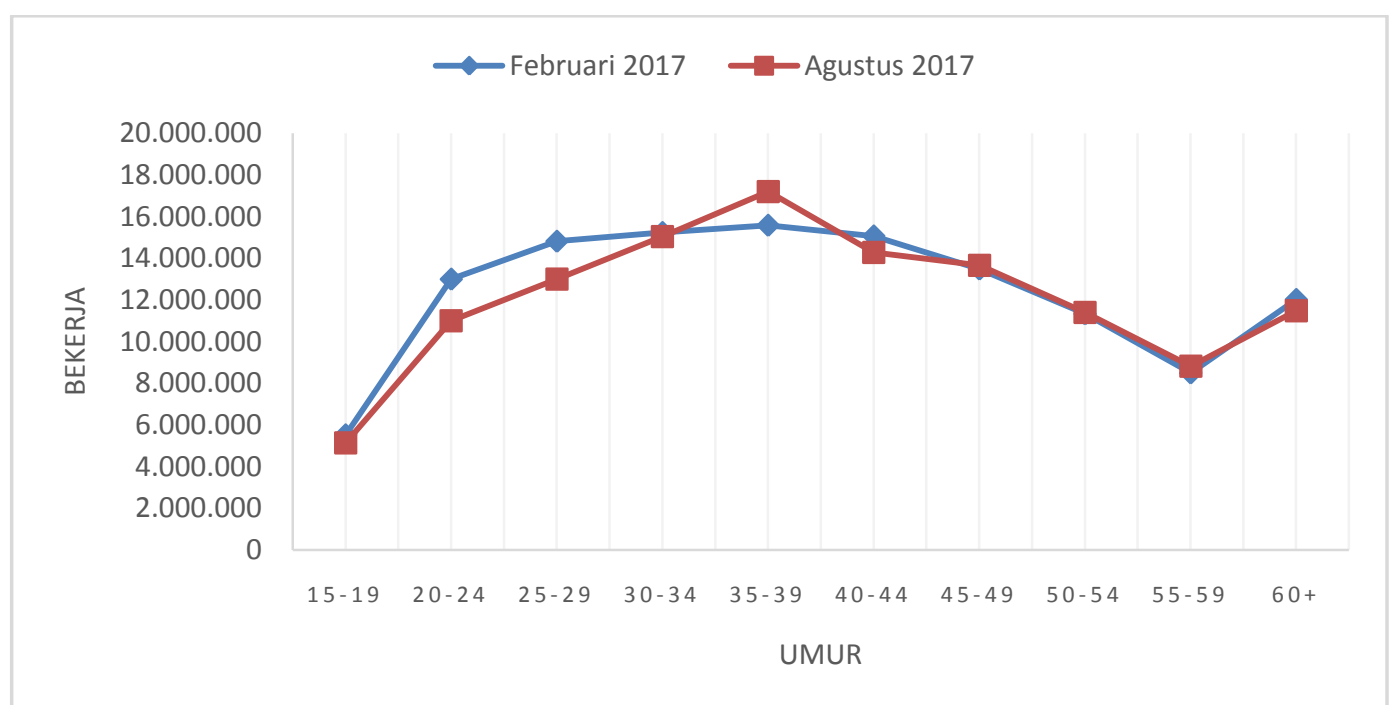

Gambar 1. Grafik Angkatan Kerja Berdasarkan Umur

Sumber: Data BPS

Berdasarkan gambar 1, dapat di simpulkan data angkatan kerja berdasarkan umur yang dimiliki oleh BPS menunjukkan adanya peningkatan yang signifikan pada angkatan kerja dengan golongan umur 35-39 tahun, dari 15.577.244 angkatan kerja yang bekerja menjadi 17.202.398 (atau kenaikan jumlah angkatan kerja yang bekerja sebanyak 1.625.154). Berdasarkan rata-rata pada data per Agustus 2017, terjadi penurunan pada sebagai besar rentang umur, namun pada golongan umur tertentu terdapat sedikit kenaikan pada angka 500 ribu angkatan kerja. BPS juga memiliki data berdasarkan status pekerjaan utama per 2017 seperti berikut ini. Berangkat dari pertimbangan itu, beberapa peubah yang diduga menyebabkan hal tersebut dapat muncul, diantaranya kompensasi, pengembangan karier, dukungan sosial yang memengaruhi kesetiaan melalui kualitas kehidupan kerja dan kinerja dari individu tersebut.

\section{TINJAUAN PUSTAKA}

\section{Kesetiaan}

Turkyilmaz et al. (2011;(Ibrahim \& Al Falasi, 2014) menyoroti bahwa kesetiaan adalah keadaan psikologis yang menggambarkan hubungan antara karyawan dan organisasinya; hubungan ini berimplikasi pada keputusan mereka untuk tetap tinggal atau tidak dengan organisasi tersebut. Kesetiaan dianggap sebagai keinginan kuat untuk terus menjadi anggota sebuah organisasi (Ibrahim \& Al Falasi, 2014). Mohsan et al. (2011; (Ibrahim \& Al Falasi, 2014) telah menyebutkan beberapa definisi dari komitmen organisasi diantaranya, O'Reilly dan Chatman (1986; (Ibrahim \& Al Falasi, 2014) menganggap komitmen berorganisasi sebagai keterikatan psikologis yang dirasakan oleh karyawan terhadap organisasinya; Begin (1997; (Ibrahim \& Al Falasi, 2014) melihat komitmen berorganisasi sebagai kesetiaan dan dukungan yang diberikan oleh tempat kerja untuk mencapai tujuan organisasi; Holden (1998; (Ibrahim \& Al Falasi, 2014) mendefinisikannya sebagai upaya yang dilakukan oleh seorang karyawan untuk mencapai tujuan organisasi; Greenberg dan Baron (2000; (Ibrahim \& Al Falasi, 


\section{National Conference of Creative Industry: \\ Sustainable Tourism Industry for Economic Development}

Universitas Bunda Mulia, Jakarta, 5-6 September 2018 e-ISSN No: 2622-7436

2014)menggambarkan sebagai sejauh mana seorang karyawan terlibat dalam organisasi tersebut dan tidak mau meninggalkannya. Linz, Good, \& Busch(2015) menyatakan loyalitas terkadang diukur dengan menggunakan senioritas atau niat untuk berhenti, dan menggunakan ukuran gabungan kesetiaan pekerja yang berfokus pada komitmen dan keterlibatan organisasi. Blomme dkk. (2010; (Seopa, Wöcke, \& Leeds, 2015) mendefinisikan komitmen organisasi sebagai keadaan psikologis yang mencirikan hubungan karyawan dengan organisasinya dan berimplikasi pada keputusan untuk melanjutkan atau menghentikan keanggotaan dalam organisasi. Ini dapat digambarkan sebagai identifikasi yang kuat dengan dan keterlibatan dalam organisasi dan tercermin dalam penerimaan karyawan terhadap tujuan organisasi, kesediaan untuk bekerja keras untuk organisasi dan keinginan untuk tinggal di organisasi. Cooper-Hakim dan Viswesvaran (2005; (Seopa et al., 2015) berpendapat bahwa komitmen berkembang perlahan dan konsisten seiring waktu sebagai hasil dari hubungan pemberi kerja dengan karyawan.Komitmen organisasi didefinisikan sebagai identifikasi yang kuat dengan dan keterlibatan dalam organisasi dan itu tercermin dari penerimaan karyawan terhadap tujuan organisasi, kesediaan untuk bekerja keras untuk organisasi dan keinginan untuk tetap bersama organisasi (Seopa et al., 2015). Diusulkan oleh Schaufeli et al. (2002, (Bui, Zeng, \& Higgs, 2017): "kondisi pikiran yang positif, memuaskan, dan berhubungan dengan pekerjaan yang dicirikan oleh kekuatan, dedikasi, dan penyerapan". Semangat mengacu pada tingkat energi dan ketahanan psikologis yang lebih tinggi saat bekerja. Dedikasi dicirikan oleh rasa motivasi, antusiasme, kebanggaan, dan tantangan. Penyerapan berarti bahwa seseorang benar-benar berkonsentrasi pada, dan menolak untuk berhenti, pekerjaan mereka. Ketiga komponen ini juga disebut sebagai: fisik, emosional, dan kognitif (Seopa et al., 2015).

\section{Kompensasi}

Kompensasi meruapakan imbalan berupa uang atau bukan uang (natura), yang diberikan kepada karyawan dalam perusahaan atau organisasi. Menurut (Türk, 2008), perusahaan memutuskan untuk memberi kompensasi kepada karyawan bukan hanya berdasarkan pada input individu, tetapi perlu mengetahui potensi dan kemampuan karyawan tersebut. Praktik kompensasi telah ditemukan memiliki nilai tambah lebih besar bila digunakan untuk mendukung praktik kerja, manajemen mutu, atau budaya perusahaan yang tinggi (Chênevert \& Tremblay, 2011). Menurut Burke (2016) skema peubah-peubah pembayaran di dalam remunerasi individu, kelompok, dan organisasi dapat berupa bonus, insentif, bonus on-the-spot, pembagian keuntungan, dan berbagai skema pembayaran lain untuk kinerja lainnya. Hal tersebut pada dasarnya didasarkan pada sebuah prinsip yang menunjukkan bahwa gaji seorang individu harus bervariasi berdasarkan kinerja (individu, kelompok, atau organisasi). Di sisi lain alat kompensasi tetap sudah ditentukan, seperti metode pembayaran gaji langsung. Pergeseran ke kompensasi yang lebih bervariasi juga membantu mengurangi titik impas sebuah perusahaan (total biaya tetap / biaya variabel harga), yang menyebabkan perusahaan dapat menghasilkan keuntungan lebih cepat (Burke, 2016). Pertama, karena proporsi variabel dari total kompensasi meningkat, banyak karyawan mungkin menuntut tingkat upah yang lebih tinggi karena risiko ekstra yang mereka ambil (Burke, 2016). Kedua, karyawan yang berpenghasilan pendapatan lebih rendah, kurang bersedia untuk membagi gaji mereka ke beberapa komponen peubah (Burke, 2016). Lebih khusus lagi, Caroli dan Garcia-Penalosa (2002; Burke, 2016) mengemukakan sebuah model, di mana pekerja menjadi lebih tidak menyukai risiko (yaitu bersedia mengambil risiko lebih 


\section{National Conference of Creative Industry: \\ Sustainable Tourism Industry for Economic Development}

Universitas Bunda Mulia, Jakarta, 5-6 September 2018 e-ISSN No: 2622-7436

banyak) hanya karena pendapatan mereka tumbuh, dan kemudian beralih dari kontrak upah tetap ke variabel gaji. Dengan demikian, perusahaan yang menekankan komponen pembayaran variabel dalam pekerjaan dengan gaji rendah mungkin mengalami kesulitan dalam menarik karyawan ke pekerjaan tersebut dan pada akhirnya menciptakan lebih banyak omset bagi karyawan yang tidak menginginkan unsur variabel dalam paket kompensasi mereka. Untuk kinerja optimal, sistem kompensasi harus terdiri dari kebijakan yang konsisten baik di antara mereka sendiri maupun dengan kebijakan SDM lainnya (Chênevert \& Tremblay, 2011).

\section{Pengembangan Karier}

Wrzesniewski et al. (1997; (John, 2013) menguraikan perbedaan antara pekerjaan, karier dan panggilan dengan mendefinisikan pekerjaan adalah hubungan kerja yang semata-mata didasarkan pada manfaat material, karier merupakan kemajuan melalui struktur pekerjaan, dan panggilan sebagai posisi kerja yang tidak dapat dipisahkan dari proyek kehidupan individu yang lebih luas. Pengembangan karier melalui kacamata karier Boundaryless atau Protean memberi penekanan pada konteks menyeluruh di kehidupan tenaga kerja (John, 2013), manfaat dari perencanaan karier dapat digunakan untuk menemukan makna atau memahami identitas diri sendiri (John, 2013) dan menekankan pada penilaian subjektif terhadap kesuksesan secara psikologis, sebagai tujuan pengembangan karier (John, 2013), yang lebih berorientasi pada pengembangan pribadi. Karyawan yang diberikan pengembangan dapat memperoleh akses ke pelatih untuk meningkatkan keterampilan kepemimpinan mereka, menerima tugas yang memenuhi tujuan karier mereka, mendapatkan pengembangan karir yang difasilitasi, atau mendapatkan keuntungan dari kesempatan belajar dan pertumbuhan tambahan (Guerrero, 2016). Meskipun pengembangan secara alami, mengacu pada pengaturan yang menjamin pengembangan dan kemajuan profesional, bagaimana kaitannya dengan kesuksesan karir belum diselidiki. Makalah ini mengusulkan langkah pertama ke arah itu. Sejalan dengan perspektif mobilitas yang disponsori (Guerrero, 2016), kami mengkonseptualisasikan pengembangan sebagai contoh sponsor organisasi, dan mengusulkan yang pertama, mengelola karir seseorang secara proaktif melalui perencanaan karier secara positif terkait dengan pengembangan; dan kedua, pengembangan secara positif mempengaruhi kesuksesan karir obyektif dan subyektif dengan memberikan dukungan dan sumber daya penerima untuk pengembangan profesional yang tidak diperoleh rekan lainnya. Pengembangan karyawan membutuhkan kesadaran, yang didefinisikan sebagai upaya pribadi karyawan untuk mengidentifikasi kebutuhan dan peluang mereka sendiri untuk mengembangkan pengetahuan, keterampilan, dan kemampuan (Park et al, 2017). Pengembangan karier membutuhkan kesadaran melibatkan penilaian diri dari kekuatan dan kelemahan sendiri serta upaya sendiri untuk mengeksplorasi peluang yang tersedia untuk mengembangkan dan meningkatkan keterampilan profesional, pengetahuan, dan sikap baik melalui pelatihan formal atau informal (Park et al, 2017). Pelatihan, bersama dengan dukungan lainnya, adalah investasi organisasi yang penting pada karyawan yang menghasilkan dukungan organisasi dan hasil yang lebih tinggi (Park et al, 2017). Dukungan pelatihan dan pengembangan dari supervisi mencakup dorongan, umpan balik, membantu karyawan mengidentifikasi peluang untuk memperoleh pengetahuan, keterampilan, dan sikap baru, dan mempromosikan penerapan kompetensi ini di tempat kerja (Park et al, 2017). 


\section{National Conference of Creative Industry: \\ Sustainable Tourism Industry for Economic Development}

Universitas Bunda Mulia, Jakarta, 5-6 September 2018

e-ISSN No: 2622-7436

\section{Dukungan Sosial}

Dukungan sosial dianggap sebagai faktor penting dalam mengatasi stres kerja dengan menyediakan hubungan interpersonal yang dapat diandalkan yang menghasilkan inklusi, jaminan, bimbingan, dan bantuan material (Moeller \& Chung-Yan, 2013). Dampak positif dari dukungan sosial diperkirakan terjadi karena adanya pengalaman dan sumber daya yang positif yang menjadikan stres kurang mengancam dan meningkatkan kemampuan individu untuk mengatasi stres (Moeller \& Chung-Yan, 2013). Dukungan sosial dapat di klasifikasikan menurut sumber pendukung (misalnya rekan kerja atau supervisor) dan jenis dukungan, termasuk dukungan instrumental, emosional, informasi, dan penilaian atau appraisal (Moeller \& Chung-Yan, 2013). Dukungan instrumental terdiri dari menawarkan bantuan yang dapat dilihat atau bantuan nyata (Moeller \& Chung-Yan, 2013). Dukungan emosional termasuk ke dalam mendengarkan dan menunjukkan simpati atau kepercayaan (Moeller \& Chung-Yan, 2013). Dukungan informasi melibatkan saran tentang bagaimana menghadapi suatu masalah serta informasi dan arahan yang berguna (Moeller \& Chung-Yan, 2013). Dukungan penilaian mencakup menawarkan umpan balik atau saran untuk mengevaluasi situasi tertentu (Moeller \& Chung-Yan, 2013). Dukungan penilaian serupa dengan dukungan informasi karena memerlukan informasi; Namun, informasi ini hanya relevan untuk evaluasi diri seseorang, bukan pada masalah secara keseluruhan (Moeller \& Chung-Yan, 2013). Meskipun jenis dukungan ini dapat dianggap tumpang tindih, penelitian menunjukkan bahwa dukungan instrumental, emosional, informasi, dan penilaian adalah jenis dukungan sosial yang berbeda (Moeller \& Chung-Yan, 2013). Menurut Eisenberger et al (2002; Yadav dan Naim, 2017) dukungan atasan mengacu pada pandangan umum karyawan mengenai sejauh mana supervisor menilai kontribusi dan perhatian mereka tentang kesejahteraan mereka. Dukungan melibatkan ekspresi perhatian umum atau bantuan nyata oleh supervisor yang dimaksudkan untuk meningkatkan kesejahteraan bawahan, membantu mereka dalam masalah yang terkait dengan pekerjaan, dan memfasilitasi pengembangan keterampilan mereka (Yadav dan Naim, 2017). Supervisor menunjukkan dukungan mereka terhadap bawahan dengan menjawab pertanyaan mereka, memberikan saran, membimbing pengembangan karir, dan mendengarkan kekhawatiran dan keluhan mereka (Ng dan Sorensen, 2008; Yadav dan Naim, 2017). Telah diamati bahwa pengawas dan orang lain dalam posisi kepemimpinan biasanya memiliki kekuatan posisional untuk menyalurkan sumber daya organisasi, penghargaan, tugas, dan peluang di tempat kerja (Yadav dan Naim, 2017).Menurut Nada (2016) dukungan organisasi adalah konstruk klasik dalam hubungan kerja, dan di definisikan sebagai kepercayaan karyawan bahwa organisasi menghargai kontribusi karyawan tersebut dan memperhatikan kesejahteraan mereka. Dukungan organisasi secara signifikan memengaruhi kualitas hubungan antara atasanbawahan (Nada, 2016) dan memprediksi keterlibatan karyawan (Nada, 2016), komitmen organisasi, perilaku kewarganegaraan, dan retensi (Nada, 2016). Studi Biswas dan Bhatnagar (2013; Nada, 2016) menunjukkan efek langsung dari fit persona organisasi dan dukungan organisasi terhadap keterlibatan karyawan yang menyebabkan perbedaan dalam komitmen berorganisasi dan kepuasan kerja. Selanjutnya, Gillet et al. (2013; (Al Mehrzi \&\& Kumar, 2016) menemukan bahwa karyawan yang merasa didukung oleh organisasinya, melalui pengakuan dan wewenang, menunjukkan tingkat motivasi dan keterlibatan kerja yang lebih tinggi. Oleh karena itu, karyawan dari organisasi yang dapat memastikan dukungan organisasi diharapkan memiliki keunggulan kompetitif 


\section{National Conference of Creative Industry: \\ Sustainable Tourism Industry for Economic Development}

Universitas Bunda Mulia, Jakarta, 5-6 September 2018 e-ISSN No: 2622-7436

dibandingkan organisasi yang tidak mendorong keterikatan emosional pekerja mereka (Al Mehrzi \&\& Kumar, 2016). Serta menurut (Crothers et al., 2010)bahwa aspek pekerjaan mereka yang paling memuaskan termasuk diantaranya hubungan interpersonal dengan kolega mereka, otonomi, kesempatan untuk aktif dalam karir mereka, dan kemampuan untuk memberikan layanan yang berarti, yang selaras dengan nilai-nilai moral.

\section{Kinerja}

Kinerja adalah perilaku karyawan dalam melakukan pekerjaannya (Ragas et al, 2017). Menurut Borman dan Motowidlo (1993; Ragas et al, 2017), perilaku ini termasuk kedalam seberapa banyak tenaga kerja tersebut berkontribusi dan membentuk organisasi mereka.Kinerja mengukur tujuan seorang individu, dengan penekanan pada apakah hasil kinerja sesuai dengan tujuan yang diharapkan (Yang \& Hwang, 2014). Hall dan Goodale (1986; (Yang \& Hwang, 2014) menjelaskan bahwa kinerja kerja adalah bagaimana seorang karyawan melakukan tugasnya dengan menggunakan waktu, teknik dan interaksi dengan orang lain. Schermerhorn (1989; (Yang \& Hwang, 2014) berpendapat bahwa kinerja mewakili kuantitas dan kualitas dari pekerjaan yang dicapai oleh individu atau kelompok, yang menekankan pada seberapa tercapai dan efektifnya tugas tersebut telah dilaksanakan. Literatur yang ada mengenai kinerja menunjukkan bahwa ada dua bentuk kinerja kerja - peran dan peran ekstra (Biswas, 2011). Kinerja dalam peran mengacu pada tindakan karyawan untuk memenuhi persyaratan deskripsi pekerjaannya (Biswas, 2011), sedangkan kinerja ekstra peran mengacu pada tindakan di luar persyaratan peran formal dan sesuai dengan kebijaksanaan karyawan (Biswas, 2011). Dalam hubungan ini, penelitian menunjukkan bahwa praktik pengelolaan partisipatif seperti komunikasi terbuka dan gaya kepemimpinan partisipatif akan dikaitkan secara positif dengan tingkat kinerja karyawan yang lebih tinggi, baik dalam peran dan kinerja ekstra peran. Memang, praktik semacam itu akan meningkatkan tingkat kepuasan kerja karyawan yang menghasilkan kinerja yang lebih baik. Studi yang menyelidiki hubungan antara emosi dan kinerja sangat mendukung gagasan bahwa karyawan yang bahagia bekerja lebih baik daripada karyawan yang tidak bahagia (Wright et al., 2002; (Tims, Bakker, \& Derks, 2014). Karyawan yang bahagia lebih sensitif terhadap peluang di lingkungan kerja mereka, lebih terbuka dan membantu rekan kerja mereka, dan lebih optimis dan percaya diri; pada gilirannya, atribut-atribut ini dapat menghasilkan kinerja yang lebih baik (Cropanzano dan Wright, 2001; (Tims, Bakker, \& Derks, 2014).Zelenski et al (2008; (Tims, Bakker, \& Derks, 2014) menunjukkan bahwa pengaruh positif sangat terkait dengan kinerja, dibandingkan dengan kepuasan kerja, kepuasan hidup, dan kualitas kehidupan kerja. Pengaruh positif diukur dengan deskriptor emosi positif, seperti antusias, bersemangat, dan gembira, yang sesuai dengan ukuran kenikmatan kerja yang digunakan dalam penelitian ini. Emosi positif ditemukan untuk memperluas perhatian, pemikiran, dan perilaku seseorang, serta untuk membangun sumber daya pribadi seseorang yang abadi, yang mungkin berhubungan dengan kinerja yang lebih baik (Fredrickson, 1998; (Tims, Bakker, \& Derks, 2014).

\section{Kualitas Kehidupan Kerja}

Konsep Kualitas Kehidupan Kerja atau Quality Work of Life muncul pertama kali dari Model Karakteristik pekerjaan dari Hackman dan Oldham (1976; (Chan \& Wyatt, 


\section{National Conference of Creative Industry: \\ Sustainable Tourism Industry for Economic Development}

Universitas Bunda Mulia, Jakarta, 5-6 September 2018 e-ISSN No: 2622-7436

2007). Model ini mencoba memahami bagaimana kebutuhan pertumbuhan psikologis para karyawan memengaruhi motivasi internal mereka untuk bekerja secara efektif dalam pekerjaan mereka. Hackman dan Oldham (1976; (Chan \& Wyatt, 2007) menyatakan bahwa aspek psikologis pekerjaan jarang dianggap penting, namun hal tersebut paling berkontribusi terhadap peningkatan motivasi intrinsik karyawan, yang pada akhirnya menghasilkan kinerja pekerjaan yang superior (Chan \& Wyatt, 2007). Kualitas Kehidupan Kerja dapat di definisikan sebagai kondisi yang menguntungkan dan lingkungan kerja yang mendukung dan meningkatkan kepuasan karyawan dengan menyediakan imbalan, keamanan kerja dan pengembangan pertumbuhan untuk si tenaga kerja (Chan \& Wyatt, 2007). Sedangkan menurut Robbins (1989; Rastogi et al, 2017), kualitas kehidpan kerja adalah suatu proses dimana organisasi merespon kebutuhan karyawan dengan mengembangkan mekanisme untuk memungkinkan mereka untuk berbagi secara penuh dalam membuat keputusan yang merancang kehidupan mereka di tempat kerja, sementara beberapa peneliti (seperti Carlson et al., 2003; Rastogi et al, 2017) membuat konsep kualitas kehidupam kerja sebagai tujuan dan proses berkelanjutan untuk mencapai tujuan tersebut. Sebagai tujuan, kualitas kehidupan kerja adalah komitmen dari setiap organisasi untuk meningkatkan lingkungan kerja: penciptaan lebih banyak pekerjaan yang melibatkan, memuaskan, efektif dan lingkungan kerja bagi orang-orang di semua tingkat organisasi. Sebagai sebuah proses, kualitas kehidupan kerja menyerukan upaya untuk mewujudkan tujuan ini melalui keterlibatan aktif orang-orang di seluruh organisasi. Beberapa peneliti telah mendefinisikan kualitas kehidupan kerja sebagai cara berpikir (Rastogi et al, 2017).Lebih lanjut, berakar pada klasifikasi kebutuhan, yaitu kebutuhan primer atau pertama dan kebutuhan sekunder atau kebutuhan tingkat tinggi oleh Maslow (1954, Rastogi et al, 2017), Sirgy et al. (2001; Rastogi et al, 2017) berusaha untuk mengusulkan bahwa kebutuhan yang terkait dengan kualitas kehidupan kerja dapat dibagi lagi menjadi dua bagian - kualitas kehidupan kerja tingkat rendah yang menyiratkan tingkat di mana karyawan merasakan keselamatan mereka, dan ekonomi, kebutuhan yang berhubungan dengan kesehatan terpenuhi di tempat kerja; dan kualitas kehidupankerja tingkat tinggi yang menunjukkan tingkat di mana karyawan merasakan aktualisasi, harga diri, estetika, dan kebutuhan yang terkait dengan pengetahuan mereka merasa puas di tempat kerja.Brayfield dan Rothe (1951; Ainsworth, 2016) mengembangkan indeks kepuasan kerja, yang didasarkan pada sikap karyawan terhadap pekerjaan mereka. Kalleberg (1977; Ainsworth 2016) mendefinisikan kepuasan kerja sebagai "orientasi afektif keseluruhan individu terhadap peran pekerjaan yang mereka hadapi saat ini". Menurut Macdonald dan MacIntyre (1997; Ainsworth 2016) membedakan kepuasan kerja dari semangat kerja karyawan, dengan alasan bahwa kepuasan kerja mengacu pada satu individu dan situasi pekerjaannya, selanjutnya kepuasan kerja lebih tepat untuk menangani situasi lalu dan sekarang. Keamanan kerja, sistem penghargaan yang lebih baik, gaji yang lebih tinggi, kesempatan untuk bertumbuh dan meningkatkan produktivitas organisasi merupakan isu utama yang dibahas dalam literatur kualitas kehidupan kerja.

\section{Kaitan Antara Kompensasi Dan Kualitas Kehidupan Kerja}

Sifat ekstrinsik pekerjaan seperti upah dan gaji, insentif, fasilitas dan manfaat lainnya masih lebih penting untuk mempertahankan kualitas kehidupan kerja daripada sifat intrinsik pekerjaan seperti pekerjaan yang berarti dan otonomi kerja di tempat 


\section{National Conference of Creative Industry: \\ Sustainable Tourism Industry for Economic Development}

Universitas Bunda Mulia, Jakarta, 5-6 September 2018 e-ISSN No: 2622-7436

kerja. Keamanan kerja dan lingkungan kerja yang baik diperlukan untuk meningkatkan kualitas hidup kerja (Adhikari, Hirasawa, Takakubo, \& Pandey, 2012). Wan and Chan (2013; Jung et al, 2018) menemukan bahwa karyawan lebih peduli tentang gaji mereka, yang dapat mengarahkan ke kualitas kehidupan kerja yang positif, dan menyeimbangkan kondisi yang tidak menguntungkan di tempat kerja.

Berdasarkan pemaparan teori dan hasil penelitian terdahulu diatas dapat dibangun hipotesis sebagai berikut:

\section{H1: Kompensasi berpengaruh terhadap kualitas kehidupan kerja}

\section{Kaitan Antara Kompensasi Dan Kinerja}

Menurut teori human capital, karyawan dengan pendidikan yang lebih tinggi dan keterampilan yang lebih tinggi harus mendapatkan gaji yang lebih tinggi karena mereka lebih produktif (Paul dan Morris, 2014).(Türk, 2008) menjelaskan kompensasi berdasarkan output atau hasil merupakan pilihan yang lebih baik dibandingkan dengan penetapan kompensasi berdasarkan potensi dan kemampuan karyawan, hal tersebut belum cukup untuk memprediksi kinerja dan menjadi pertimbangan yang lebih besar terkait dengan tujuan yang diharapkan. Mayoritas peneliti mendukung kompensasi terkait hasil kerja, namun beberapa peneliti juga menaruh perhatian soal kaitan bagaimana cara mengukur produktivitas karyawan dan kerap kali hal tersebut menjadi pemicu kesalahan dalam sistem pengupahan berdasarkan kinerja (Türk, 2008). Beberapa studi tentang teori agensi berusaha menghubungkan struktur kompensasi dengan kinerja dan memberikan gambaran luas tentang penelitian kompensasi eksekutif dalam literatur keuangan. Selama 20 tahun, peneliti keuangan telah menyelidiki hubungan antara struktur kompensasi dan nilai perusahaan, serta sensitivitas kompensasi eksekutif terhadap perubahan harga saham atau revisi dalam kontrak kompensasi setelah kinerja buruk (Basuroy, 2014). Basuroy (2014) berpendapat bahwa pendekatan yang lebih holistik terhadap kinerja harus dipertimbangkan oleh perusahaan karena faktor-faktor yang memengaruhi nilai pasar mungkin bersifat endogen dengan dampak positif terhadap ukuran kinerja non-keuangan. Pendekatan balanced scorecard terhadap pengukuran kinerja tidak hanya memperhitungkan metrik kinerja keuangan tetapi juga perspektif pelanggan, perspektif bisnis internal dan perspektif pembelajaran dan pertumbuhan (orientasi jangka panjang). Secara khusus, sistem balanced scorecard memerlukan dewan dan tim manajemen puncak untuk menilai penggerak kinerja dan kompensasi terhadap pendorong kinerja secara keseluruhan. Dengan demikian, dari pendekatan balanced scorecard, insentif untuk terlibat dalam strategi yang meningkatkan kepuasan pelanggan melalui pilihan tata kelola, termasuk struktur kompensasi eksekutif, akan dikaitkan secara positif dengan kepuasan pelanggan dan juga kinerja perusahaan secara keseluruhan yang lebih baik (Basuroy 2014). Chênevert (2011) menunjukkan bahwa kebijakan kompensasi berdasarkan kinerja individu atau kelompok juga dapat meningkatkan kinerja organisasi. Sesuai dengan teori harapan, Chênevert (2011) telah menunjukkan bahwa program pembayaran kinerja individu meningkatkan persepsi karyawan terhadap kinerja / instrumen penghargaan. Chênevert (2011) menunjukkan bahwa perilaku yang disebabkan oleh gaji individu untuk program kinerja dapat meningkatkan kinerja organisasi. Chênevert (2011) menegaskan bahwa penerapan program berdasarkan kinerja kelompok (misalnya pembagian keuntungan) secara signifikan meningkatkan tingkat varians yang diakibatkan oleh kinerja keuangan. Menurut teori agensi Chênevert (2011), kebijakan kompensasi berdasarkan kinerja 


\section{National Conference of Creative Industry: \\ Sustainable Tourism Industry for Economic Development}

Universitas Bunda Mulia, Jakarta, 5-6 September 2018 e-ISSN No: 2622-7436

kelompok menurunkan perilaku nonproduktif dengan menyalurkan sebagian keuntungan atau kerugiannya ke dalam insentif kelompok. Oleh karena itu karyawan didorong untuk berkolaborasi satu sama lain dan dengan manajemen, karena maksimalisasi usaha mereka dan imbalan yang dihasilkan akan memberi efek positif pada pendapatan mereka dan akan menyatukan kepentingan para pihak (Chênevert, 2011)

Berdasarkan pemaparan teori dan hasil penelitian terdahulu diatas dapat dibangun hipotesis sebagai berikut:

\section{H2: Kompensasi berpengaruh terhadap kinerja}

\section{Kaitan Antara Pengembangan Karier Dan Kualitas Kehidupan Kerja}

Baruch (2004, Li 2011) mengusulkan model Career Active System Triad (CAST) yang membahas mengenai kualitas kehidupan kerja dan perencanaan pengembangan karier. Model tersebut meneliti hubungan individu dan organisasi dengan menggunakan tiga tingkat analisis: nilai, pendekatan, dan perilaku. Dari perspektif individu, ketiga tingkat analisis tersebut diterjemahkan ke dalam aspirasi, sikap, dan tindakan. Namun, dari perspektif organisasi, ketiga tingkat analisis tersebut diterjemahkan ke dalam filosofi, kebijakan, dan praktik. Agar diskusi mengenai kualitas kehidupan kerja dan perencanaan pengembangan karier tidak hanya mempertimbangkan pengaruh dari dimensi individu dan organisasi, tetapi juga pengaruh dari dimensi internal dan eksternal. Untuk mengetahui bagaimana persepsi karyawan terhadap pekerjaan mereka yang memengaruhi kualitas kehidupan kerja dan perencanaan pengembangan karier ( $\mathrm{Li}$ 2011).

Berdasarkan pemaparan teori dan hasil penelitian terdahulu diatas dapat dibangun hipotesis sebagai berikut:

\section{H3: Pengembangan karier berpengaruh terhadap kualitas kehidupan kerja}

\section{Kaitan Antara Pengembangan Karier Dan Kinerja}

Bish (2004) menemukan ada efek yang kuat bagi penerima aktivitas pengembangan, dimana peserta melaporkan tanggapan positif lebih banyak saat mereka menerima aktivitas pengembangan karier, dimana hal tersebut sering terlewat dari kinerja mereka sendiri. Bish (2004) memaparkan ada semakin banyak bukti bahwa kinerja melibatkan lebih dari sekadar performa tugas, lebih dari sekadar menerapkan seperangkat keterampilan dan pengetahuan. Banyak studi telah menunjukkan perbedaan antara kinerja tugas dan kinerja kontekstual (Bish 2004). Kinerja kontekstual mengacu pada perilaku yang mendukung konteks organisasi, psikologis dan sosial di mana tugas dilakukan (Bish 2004). Hubungan antara pelatihan dan kinerja kerja mungkin dapat dijelaskan dengan baik oleh dukungan yang diterima peserta di tempat kerja ketika menggunakan pengetahuan dan keterampilan yang baru mereka peroleh (Park et al, 2017).

Berdasarkan pemaparan teori dan hasil penelitian terdahulu diatas dapat dibangun hipotesis sebagai berikut:

\section{H4: Pengembangan karier berpengaruh terhadap kinerja}




\section{National Conference of Creative Industry: \\ Sustainable Tourism Industry for Economic Development}

Universitas Bunda Mulia, Jakarta, 5-6 September 2018

e-ISSN No: 2622-7436

\section{Kaitan Antara Dukungan Sosial Dan Kualitas Kehidupan Kerja}

Dukungan sosial dapat di definisikan sebagai sejauh mana orang-orang di sekitar tenaga kerja dapat memberikan dukungan untuknya dengan menjadi pendengar yang baik atau menjadi orang yang dapat diandalkan saat membutuhkan bantuan (Ganesh, 2014). Meskipun dukungan merupakan salah satu komponen kunci dari pengalaman kualitas kehidupan kerja yang baik, terdapat beberapa penelitian empiris yang secara langsung menghubungkan dukungan sosial dengan kualitas kehidupan kerja (Ganesh, 2014). Meskipun demikian, beberapa penelitian telah menunjukkan bahwa dukungan sosial, terutama dari atasan dan rekan kerja, jelas merupakan faktor pendukung utama dalam menurunkan beberapa faktor stres terkait pekerjaan seperti ambiguitas peran, konflik peran, kelebihan peran dan juga konflik keluarga-pekerjaan (Ganesh, 2014). Satu studi di India menunjukkan bahwa dukungan atasan dan organisasi penting untuk menciptakan kualitas kehidupan kerja yang baik (Ganesh, 2014). Selain itu, supervisor yang mendukung membuat karyawan merasa bahwa organisasi juga menghargai kontribusi mereka dan peduli tentang kesejahteraan mereka karena karyawan melihat pengawas sebagai perwakilan organisasi (Yadav dan Naim, 2017). Pandangan ini didukung secara luas oleh penelitian empiris yang menunjukkan bahwa dukungan pengawas mengarah pada peningkatan dukungan organisasi (Yadav dan Naim, 2017).

Berdasarkan pemaparan teori dan hasil penelitian terdahulu diatas dapat dibangun hipotesis sebagai berikut:

\section{H5: Dukungan sosial berpengaruh terhadap kualitas kehidupan kerja}

\section{Kaitan Antara Dukungan Sosial Dan Kinerja}

Beberapa penelitian menunjukkan bahwa para tenaga kerja, yang mendapat dukungan memadai dari rekan kerja, atasan, keluarga dan teman mereka lebih dapat menyesuaikan diri dengan lingkungan sekitar (Jyoti, 2017). Lee (2010; Jyoti, 2017) mengungkapkan bahwa dukungan sosial meningkatkan efek kecerdasan pada penyesuaian. Oleh karena itu, dapat disimpulkan bahwa kecerdasan budaya, penyesuaian, pengalaman kerja di dan dukungan sosial (dari keluarga, teman, senior dan rekan kerja) memainkan peran penting dalam meningkatkan kinerja mereka (Jyoti, 2017). Karyawan yang merasakan dukungan yang mereka terima dari organisasi dan pengawas mereka, telah dipelajari sebagai kerangka penjelasan kritis untuk memahami dan memprediksi sikap dan perilaku karyawan terkait dengan kinerja (Park et al, 2017). Ada dukungan empiris yang cukup besar untuk bahwa gagasan dukungan yang dirasakan memiliki korelasi positif dengan hasil kinerja yang menguntungkan karyawan (Park et al, 2017). Menurut teori pertukaran sosial, karyawan yang mengalami dukungan organisasi tingkat tinggi diharapkan untuk bekerja lebih keras untuk meningkatkan kinerja kerja mereka. Dengan kata lain, karyawan termotivasi ketika mereka merasa bahwa organisasi mendukung mereka dan, pada gilirannya, mereka membalas dengan output kualitas tinggi (Park et al, 2017). Meta-analisis oleh Rhoades dan Eisenberger (2002; Park et al, 2017) menegaskan hubungan positif antara dukungan sosial yang dirasakan dan kinerja pekerjaan.

Berdasarkan pemaparan teori dan hasil penelitian terdahulu diatas dapat dibangun hipotesis sebagai berikut:

H6: Dukungan sosial berpengaruh terhadap kinerja 


\section{National Conference of Creative Industry: \\ Sustainable Tourism Industry for Economic Development}

Universitas Bunda Mulia, Jakarta, 5-6 September 2018

e-ISSN No: 2622-7436

\section{Kaitan Antara Kualitas Kehidupan Kerja Dan Kesetiaan}

Kualitas kehidupan kerja karyawan merupakan faktor penting untuk kelangsungan hidup organisasi (Nanjundeswaraswamy and Swamy, 2015; Jung et al, 2018), dan memahami harapan kualitas kehidupan kerja karyawan sangat penting untuk menerapkan kebijakan dan praktik yang lebih efektif (Kandasamy dan Ancheri, 2009; Jung et al, 2018). Kualitas kehidupan kerja juga mengarah pada komitmen organisasi (Tiia, 2017). Meskipun studi pertama tentang kualitas kehidupan kerja berfokus pada sektor manufaktur, literatur yang lebih baru telah menargetkan sektor jasa, karena pengaruhnya bagi sektor ekonomi (Tiia, 2017). Kualitas kehidupan kerja mempromosikan kesejahteraan dan otonomi pekerja (Tiia, 2017). Secara keseluruhan, karyawan yang bahagia adalah karyawan yang lebih produktif, berdedikasi dan setia (Tiia, 2017). Baru-baru ini, Chan (2015; Jung et al, 2018) mempelajari pentingnya kualitas kehidupan kerja untuk karyawan paruh waktu di sektor manajemen acara dan menemukan bahwa pengembangan pribadi merupakan faktor penting untuk meningkatkan persepsi karyawan tentang kualitas kehidupan kerja dan kesetiaan.

Berdasarkan pemaparan teori dan hasil penelitian terdahulu diatas dapat dibangun hipotesis sebagai berikut:

\section{H7: Kualitas kehidupan kerja berpengaruh terhadap kesetiaan}

\section{Kaitan Antara Kinerja Dan Kesetiaan}

Peneliti dan praktisi, selama bertahun-tahun, meyakini bahwa karyawan yang berkomitmen untuk setia akan cenderung produktif, dengan kata lain kesetiaan dianggap sebagai motor penggerak di balik kinerja organisasi (Ibrahim dan Falasi2012). Alessandri et al (2018) menjelaskan bahwa penelitian ekstensif telah menunjukkan hubungan yang signifikan antara kesetiaan dan kinerja. Misalnya, keterlibatan kerja telah berkorelasi dengan sejumlah indikator kinerja obyektif, subyektif, dan subyektif yang berbeda, seperti kinerja dalam peran, volume penjualan, dan inovasi (Alessandri et al, 2018). Penjelasan yang telah diberikan adalah bahwa kinerja pekerjaan efektif ketika karyawan mengalami kondisi motivasi positif dan aktif, yang dicirikan oleh kasih sayang (dedikasi), energi (semangat) dan inspirasi kognitif (penyerapan) terhadap pekerjaan. Ini adalah kondisi psikologis khusus yang memotivasi karyawan untuk bekerja keras dan bekerja dengan baik. Karyawan yang setia mendekati pekerjaan mereka secara proaktif, lebih dinamis, lebih responsif terhadap informasi baru dan bekerja lebih keras (Alessandri et al, 2018). Individu yang lebih banyak terlibat sepanjang waktu,akan menunjukkan tingkat kinerja pekerjaan yang lebih tinggi daripada individu yang dicirikan oleh tingkat keterlibatan kerja yang rendah. Selain itu, tingkat keterlibatan kerja absolut dapat mempengaruhi peningkatan kinerja dari waktu ke waktu, karena diharapkan bahwa kesetiaan kerja mengikat kemampuan individu untuk menginvestasikan upaya mereka dalam kegiatan kerja, menghasilkan peningkatan kinerja dari waktu ke waktu (Alessandri et al, 2018). Modal psikologisdapat dikonseptualisasikan sebagai ekspresi sumber daya psikologis yang sesuai dengan jumlah potensi (yaitu kemampuan, optimisme, harapan dan ketahanan) yang dimiliki oleh individu. Keterlibatan kerja mengungkapkan komponen motivasi, dan diwakili oleh investasi upaya dan keterlibatan dedikasi individu untuk bekerja. Di sisi lain, kinerja pekerjaan merupakan hasil perilaku, diakui dan dihargai oleh organisasi. Melalui proses motivasi ini (yaitu meningkatkan keterlibatan kerja) bahwa potensi (yaitu modal 


\section{National Conference of Creative Industry: \\ Sustainable Tourism Industry for Economic Development}

Universitas Bunda Mulia, Jakarta, 5-6 September 2018 e-ISSN No: 2622-7436

psikologisdan perubahan modal psikologis) diterjemahkan ke dalam perilaku organisasi yang produktif (yaitu kinerja pekerjaan yang efektif dan meningkat) (Alessandri et al, 2018).

Berdasarkan pemaparan teori dan hasil penelitian terdahulu diatas dapat dibangun hipotesis sebagai berikut:

\section{H8: Kinerja berpengaruh terhadap kesetiaan}

\section{METODE PENELITIAN}

Dalam penelitian ini peneliti menggunakan Partial Least Squares (PLS), menurut Jogiyanto dan Willy (2016) PLS adalah teknik stasitika multivariat yang melakukan pembandingan antara varaibel dependen berganda dan variabel independen berganda. PLS adalah salah satu metoda statistika SEM berbasis varian yang didesain untuk menyelesaikan regresi berganda ketika terjadi permasalahan spesifik pada data, seperti ukuran sampel penelitian kecil, adanya data yang hilang (missing values) dan multikolinearitas. Tujuan PLS adalah untuk memprediksi pengaruh variabel $X$ terhadap Y dan menjelaskan hubungan teoritikal di antara kedua variabel. PLS adalah metoda regresi yang dapat digunakan untuk identifikasi faktor yang merupakan kombinasi variabel $\mathrm{X}$ sebagai penjelas dan variabel $\mathrm{Y}$ sebagai variabel respon (Jogiyanto dan Willy, 2016). Cara pengukuran dengan menghadapkan seorang responden dengan sebuah pernyataan, lalu responden tersebut diminta untuk menjawab dengan memilih salah satu pilihan jawaban dengan masing-masing jawaban memiliki skor yang berbedabeda. Rentang skor yang digunakan pada penelitian ini mulai dari skor 1 (sangat tidak setuju) hingga skor 7 (sangat setuju). Pemilihan rentang skor 1-7 sendiri diharapkan agar responden lebih bersungguh-sungguh menjawab pernyataan karena mengharuskan mereka untuk berpikir lebih keras.

Populasi di penelitian ini merupakan seluruh generasi Y (tahun kelahiran diantara tahun 1980-2000), sudah bekerja dan menjadi karyawan tetap dan berdomisili di wilayah Jakarta, Bogor, Depok, Tangerang, Bekasi. Jumlah sampel ditentukan berdasarkan jumlah indikator dari peubah dikalikan lima hingga sepuluh. Jumlah indikator yang didapatkan dari seluruh peubah adalah sebanyak 11 indikator, maka jumlah sampel minimal yang dibutuhkan di penelitian ini sebanyak 110 orang. Namun di dalam penelitian ini jumlah sampel yang ditetapkan menjadi 120 orang, dengan pertimbangan adanya kuesioner yang cacat atau tidak bisa diolah.

\section{HASIL PENELITIAN DAN PEMBAHASAN}

Kuesioner pada penelitian ini disebar melalui 2 metode, pertama melalui metode online, kedua dengan metode tradisional atau disebar langsung di salah satu lokasi di Jakarta. Dari 120 kuesioner yang didapat, data responden dapat dikelompokkan berdasarkan jender, tahun kelahiran, domisili saat ini, tingkat pendidikan, masa kerja pada perusahaannya saat ini, sudah berpindah atau bekerja di berapa perusahaan, pengeluaran (bersih) per bulan perseorangan, bidang industri yang digeluti oleh perusahaannya. Berikut penjabaran data tersebut. 
Tabel 1 - Perbandingan Jender Dengan Tahun Kelahiran

\begin{tabular}{|l|c|c|c|}
\hline \multicolumn{1}{|c|}{ Jender } & Tahun Kelahiran & Total & Persentase \\
\hline Pria & $1980-1984$ & 8 & $6.67 \%$ \\
\hline & $1985-1989$ & 8 & $6.67 \%$ \\
\hline & $1990-1994$ & 25 & $20.83 \%$ \\
\hline Wanita & $1995-1999$ & 0 & $0.00 \%$ \\
\hline & $1980-1984$ & 6 & $5.00 \%$ \\
\hline & $1985-1989$ & 14 & $11.67 \%$ \\
\hline & $1990-1994$ & 53 & $44.17 \%$ \\
\hline & $1995-1999$ & 6 & $5.00 \%$ \\
\hline
\end{tabular}

Sumber: Hasil tabulasi data kuesioner

Tabel 2 - Data Reponden Berdasarkan Bidang Industri Perusahaan

\begin{tabular}{|l|c|c|}
\hline \multicolumn{1}{|c|}{ Bidang } & Total & Persentase \\
\hline Pertanian / Kehutanan / Perikanan & 1 & $0.83 \%$ \\
\hline Perdagangan Besar / Eceran (Retail / Wholesale) & 64 & $53.33 \%$ \\
\hline Informasi, Komunikasi \& Teknologi & 25 & $20.83 \%$ \\
\hline Real Estate / Properti & 3 & $2.50 \%$ \\
\hline Jasa Pendidikan & 8 & $6.67 \%$ \\
\hline Industri Pengolahan / Manufaktur & 2 & $1.67 \%$ \\
\hline Transportasi, Distribusi \& Pergudangan & 2 & $1.67 \%$ \\
\hline Jasa Keuangan \& Asuransi & 6 & $5.00 \%$ \\
\hline Jasa Profesional, Ilmiah \& Teknis (Konsultan, Hukum, Penelitian) & 5 & $4.17 \%$ \\
\hline Jasa Hiburan \& Rekreasi (Hotel, Taman Hiburan) & 2 & $1.67 \%$ \\
\hline Food \& Beverages (Restoran, Cafe) & 2 & $1.67 \%$ \\
\hline & $\mathbf{1 2 0}$ & $\mathbf{1 0 0 . 0 0 \%}$ \\
\hline
\end{tabular}

Sumber: Hasil tabulasi data kuesioner 


\section{Gambar 2 - Uji Instrumen PLS Algortihm}

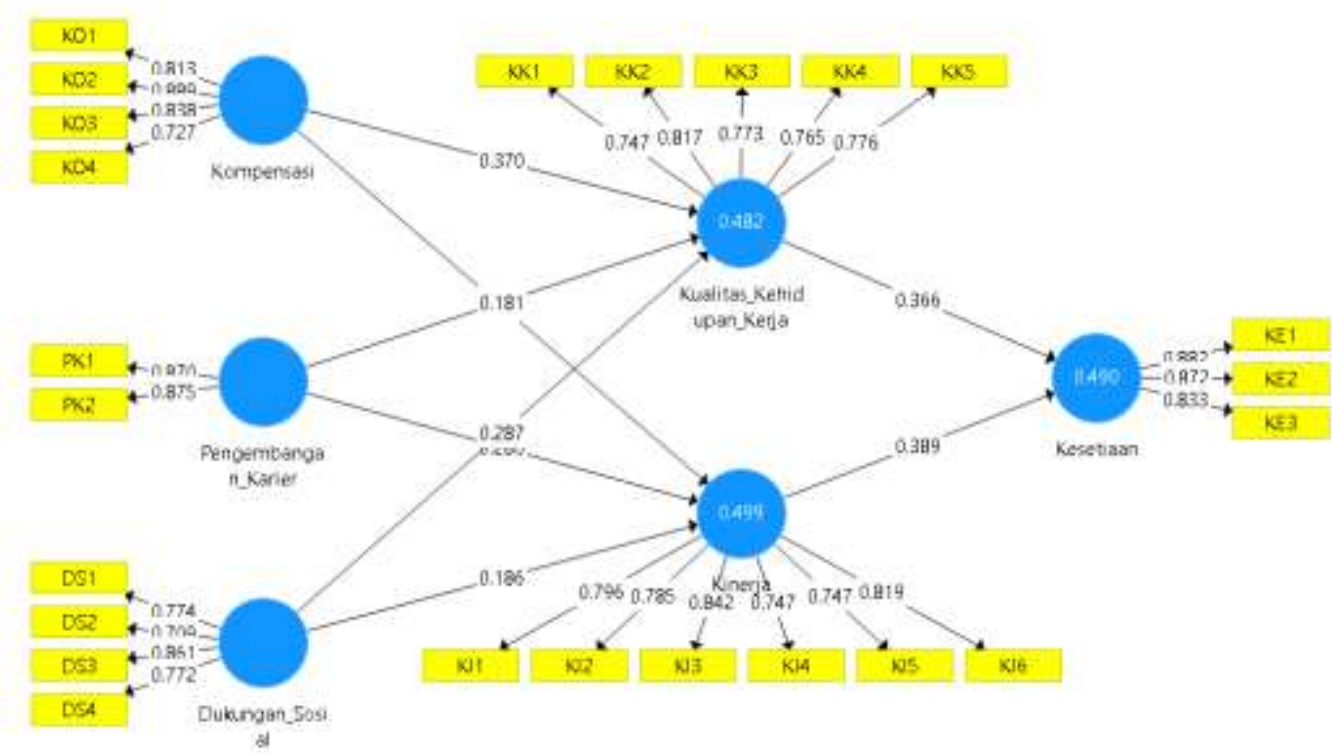

Sumber: Hasil pengolahan data dengan SmartPLS V.3.2.1

Pada gambar model PLS algorithm dapat dijelaskan bahwa gambar tersebut terdiri dari 6 peubah, 8 hipotesis dan 24 pernyataan dari data yang diperoleh pada penelitian ini. Data yang disajikan pada gambar tersebut masih berupa data primer yang belum diolah, artinya data yang didapatkan belum diolah sesuai dengan ketentuan-ketentuan yang berlaku dalam metode PLS. Berdasarkan hasil pengujian model pengukuran pada gambar di atas, dapat dijelaskan bahwa konstruk kompensasi diukur dengan menggunakan indikator KO1-KO4, konstruk pengembangan karier diukur dengan menggunakan indikator PK1-PK2 konstruk dukungan sosial diukur dengan menggunakan indikator DS1-DS4, konstruk kualitas kehidupan kerja diukur dengan menggunakan indikator KK1-KK5, konstruk kinerja diukur dengan menggunakan indikator KI1-KI6 dan konstruk kesetiaan diukur dengan menggunakan indikator KE1KE3

Tabel 3 -Overview Algorithm

\begin{tabular}{|l|l|l|l|l|}
\hline & AVE & $\begin{array}{l}\text { Composite } \\
\text { Reliability }\end{array}$ & $R$ Square & $\begin{array}{l}\text { Cronbachs } \\
\text { Alpha }\end{array}$ \\
\hline $\begin{array}{l}\text { Dukungan_Sos } \\
\text { ial }\end{array}$ & 0.610 & 0.862 & & 0.785 \\
\hline Kesetiaan & 0.744 & 0.897 & 0.490 & 0.828 \\
\hline Kinerja & 0.625 & 0.909 & 0.499 & 0.879 \\
\hline Kompensasi & 0.670 & 0.890 & & 0.834 \\
\hline $\begin{array}{l}\text { Kualitas_Kehi } \\
\text { dupan_Kerja }\end{array}$ & 0.602 & 0.883 & 0.482 & 0.837 \\
\hline $\begin{array}{l}\text { Pengembangan } \\
\text { Karier }\end{array}$ & 0.762 & 0.865 & & 0.687 \\
\hline
\end{tabular}

Sumber : Hasil pengolahan data dengan SmartPLS V.3.2.1 
National Conference of Creative Industry: Sustainable Tourism Industry for Economic Development

Universitas Bunda Mulia, Jakarta, 5-6 September 2018 e-ISSN No: 2622-7436

Tabel 4 - Korelasi Variabel Laten

\begin{tabular}{|l|llllll|}
\hline & $\begin{array}{l}\text { Dukung } \\
\text { an_Sosi } \\
\text { al }\end{array}$ & $\begin{array}{l}\text { Kesetia } \\
\text { an }\end{array}$ & Kinerja & $\begin{array}{l}\text { Kompe } \\
\text { nsasi }\end{array}$ & $\begin{array}{l}\text { Kualita } \\
\text { s_Kehi } \\
\text { dupan__ } \\
\text { Kerja }\end{array}$ & $\begin{array}{l}\text { Pengem } \\
\text { bangan } \\
\text { _Karier }\end{array}$ \\
\hline Dukungan_Sosial & 1 & & & & & \\
\hline Kesetiaan & 0.606 & 1 & & & & \\
\hline Kinerja & 0.543 & 0.651 & 1 & & & \\
\hline Kompensasi & 0.502 & 0.612 & 0.611 & 1 & & \\
\hline $\begin{array}{l}\text { Kualitas_Kehidup } \\
\text { an_Kerja }\end{array}$ & 0.577 & 0.645 & 0.714 & 0.600 & 1 & 1 \\
\hline $\begin{array}{l}\text { Pengembangan_K } \\
\text { arier }\end{array}$ & 0.578 & 0.447 & 0.575 & 0.475 & 0.522 & 1 \\
\hline Sumber:
\end{tabular}

Sumber : Hasil pengolahan data dengan SmartPLS V.3.2.1

Tabel 5 -Convergent Validity (Outer Loadings)

\begin{tabular}{|c|c|c|c|c|c|c|c|}
\hline & $\begin{array}{l}\text { Dukung } \\
\text { an_Sosia } \\
1\end{array}$ & $\begin{array}{l}\text { Kesetiaa } \\
\mathrm{n}\end{array}$ & Kinerja & $\begin{array}{l}\text { Kompen } \\
\text { sasi }\end{array}$ & $\begin{array}{l}\text { Kualitas } \\
\text { _Kehidu } \\
\text { pan_Ker } \\
\text { ja }\end{array}$ & $\begin{array}{l}\text { Pengem } \\
\text { bangan } \\
\text { Karier }\end{array}$ & Status \\
\hline DS1 & 0.774 & & & & & & Valid \\
\hline DS2 & 0.709 & & & & & & Valid \\
\hline DS3 & 0.861 & & & & & & Valid \\
\hline DS4 & 0.772 & & & & & & Valid \\
\hline KE1 & & 0.882 & & & & & Valid \\
\hline KE2 & & 0.872 & & & & & Valid \\
\hline KE3 & & 0.833 & & & & & Valid \\
\hline KI1 & & & 0.796 & & & & Valid \\
\hline $\mathrm{KI} 2$ & & & 0.785 & & & & Valid \\
\hline KI3 & & & 0.842 & & & & Valid \\
\hline KI4 & & & 0.747 & & & & Valid \\
\hline KI5 & & & 0.747 & & & & Valid \\
\hline KI6 & & & 0.819 & & & & Valid \\
\hline KK1 & & & & & 0.747 & & Valid \\
\hline KK2 & & & & & 0.817 & & Valid \\
\hline KK3 & & & & & 0.773 & & Valid \\
\hline KK4 & & & & & 0.765 & & Valid \\
\hline KK5 & & & & & 0.776 & & Valid \\
\hline KO1 & & & & 0.813 & & & Valid \\
\hline $\mathrm{KO} 2$ & & & & 0.889 & & & Valid \\
\hline KO3 & & & & 0.838 & & & Valid \\
\hline KO4 & & & & 0.727 & & & Valid \\
\hline PK1 & & & & & & 0.870 & Valid \\
\hline PK2 & & & & & & 0.875 & Valid \\
\hline
\end{tabular}


Sumber : Hasil pengolahan data dengan SmartPLS V.3.2.1

Berdasarkan hasil pada tabel 5 dapat disimpulkan bahwa seluruh indikator merupakan data yang valid karena nilainya lebih dari > 0,7, dengan skor tertinggi 0,889 untuk KO2 (kompensasi) dan skor terendah 0,709 untuk DS2 (dukungan sosial).

\section{Gambar 4.2 Model Bootstrapping}

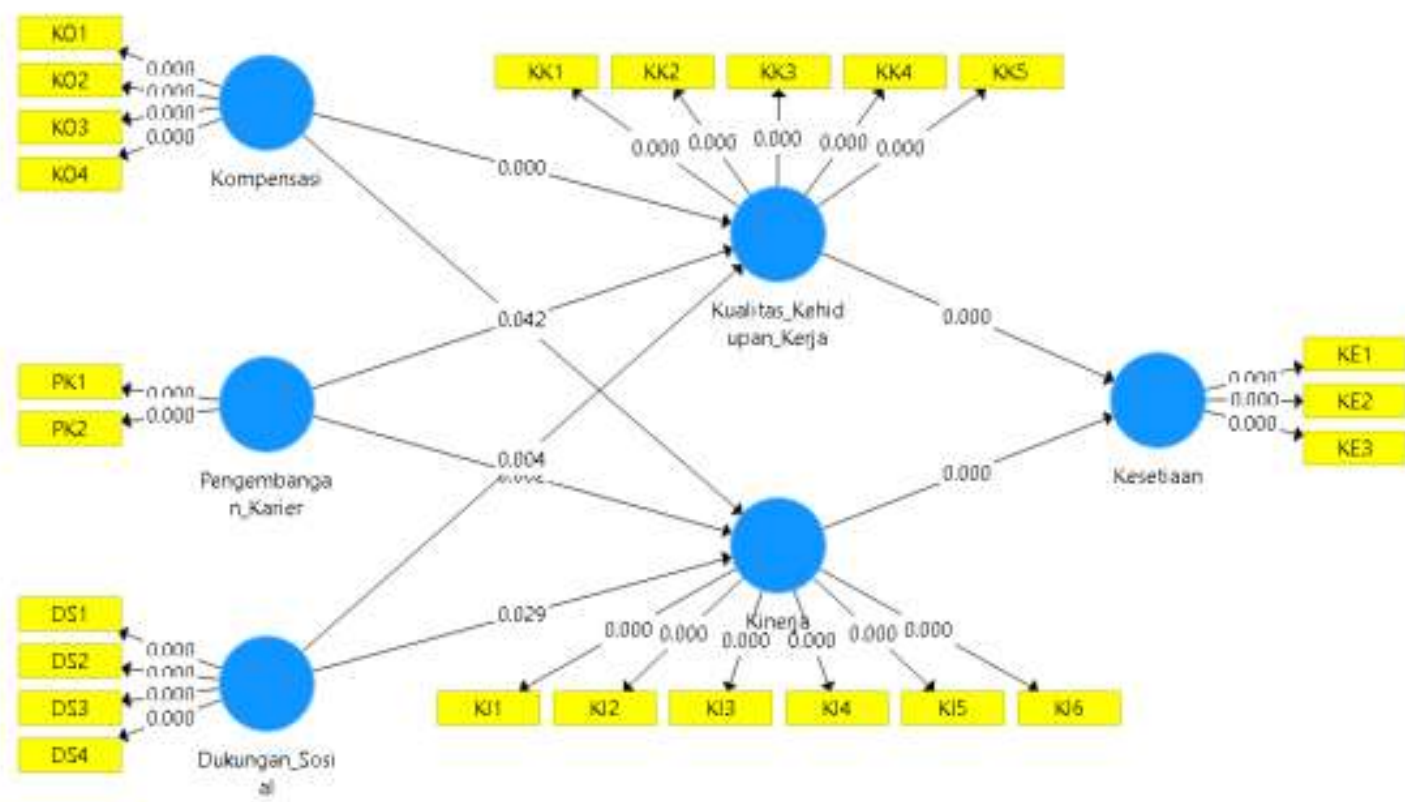

Sumber : Hasil pengolahan data dengan SmartPLS V.3.2.1

Tabel 6 -Path Coefficients

\begin{tabular}{|c|c|c|c|c|c|}
\hline & $\begin{array}{l}\text { Original } \\
\text { Sample } \\
(O)\end{array}$ & $\begin{array}{l}\text { Sample } \\
\text { Mean } \\
(M)\end{array}$ & $\begin{array}{l}\text { Standard } \\
\text { Error } \\
\text { (STERR) }\end{array}$ & $\begin{array}{l}\text { T Statistics } \\
(|O / S T E R R|)\end{array}$ & $\begin{array}{l}P \\
\text { Values }\end{array}$ \\
\hline Dukungan_Sosial -> Kinerja & 0.186 & 0.191 & 0.085 & 2.185 & 0.029 \\
\hline $\begin{array}{l}\text { Dukungan_Sosial -> } \\
\text { Kualitas_Kehidupan_Kerja }\end{array}$ & 0.287 & 0.299 & 0.100 & 2.868 & 0.004 \\
\hline Kinerja -> Kesetiaan & 0.389 & 0.390 & 0.087 & 4.492 & 0.000 \\
\hline Kompensasi -> Kinerja & 0.381 & 0.388 & 0.083 & 4.615 & 0.000 \\
\hline $\begin{array}{l}\text { Kompensasi -> } \\
\text { Kualitas_Kehidupan_Kerja }\end{array}$ & 0.370 & 0.368 & 0.095 & 3.876 & 0.000 \\
\hline $\begin{array}{l}\text { Kualitas_Kehidupan_Kerja - } \\
\text { > Kesetiaan }\end{array}$ & 0.366 & 0.371 & 0.088 & 4.159 & 0.000 \\
\hline $\begin{array}{l}\text { Pengembangan_Karier -> } \\
\text { Kinerja }\end{array}$ & 0.286 & 0.280 & 0.093 & 3.092 & 0.002 \\
\hline $\begin{array}{l}\text { Pengembangan_Karier -> } \\
\text { Kualitas_Kehidupan_Kerja }\end{array}$ & 0.181 & 0.178 & 0.089 & 2.034 & 0.042 \\
\hline
\end{tabular}

Sumber : Hasil pengolahan data dengan SmartPLS V.3.2.1 
Berdasarkan tabel diatas dapat disimpulkan bahwa seluruh hipotesis terdukung karena skor $T$-statistics lebih tinggi dibandingkan nilai $T$-table atau $\geq 1,96$ yang artinya terdapat pengaruh antara kompensasi terhadap kualitas kehidupan kerja, terdapat pengaruh antara kompensasi terhadap kinerja, terdapat pengaruh antara pengembangan karier terhadap kualitas kehidupan kerja, terdapat pengaruh antara pengembangan karier terhadap kinerja, terdapat pengaruh antara dukungan sosial terhadap kualitas kehidupan kerja, terdapat pengaruh antara dukungan sosial terhadap kinerja, terdapat pengaruh antara kualitas kehidupan kerja terhadap kesetiaan dan terdapat pengaruh antara kinerja terhadap kesetiaan.

\section{Tabel 7 -Indirect Effect}

\begin{tabular}{|c|c|c|c|c|c|}
\hline & $\begin{array}{l}\text { Origina } \\
l \\
\text { Sample } \\
(O)\end{array}$ & $\begin{array}{l}\text { Sample } \\
\text { Mean } \\
(M)\end{array}$ & $\begin{array}{l}\text { Standard } \\
\text { Error } \\
(S T E R R)\end{array}$ & $\begin{array}{l}\text { T Statistics } \\
(|O / S T E R R|)\end{array}$ & $\begin{array}{l}P \\
\text { Values }\end{array}$ \\
\hline $\begin{array}{l}\text { Dukungan_Sosial -> } \\
\text { Kesetiaan }\end{array}$ & 0.178 & 0.185 & 0.061 & 2.907 & 0.004 \\
\hline \multicolumn{6}{|l|}{ Dukungan_Sosial -> Kinerja } \\
\hline \multicolumn{6}{|l|}{$\begin{array}{l}\text { Dukungan_Sosial -> } \\
\text { Kualitas_Kehidupan_Kerja }\end{array}$} \\
\hline \multicolumn{6}{|l|}{ Kinerja -> Kesetiaan } \\
\hline Kompensasi -> Kesetiaan & 0.284 & 0.290 & 0.067 & 4.266 & 0.000 \\
\hline \multicolumn{6}{|l|}{ Kompensasi -> Kinerja } \\
\hline \multicolumn{6}{|l|}{$\begin{array}{l}\text { Kompensasi -> } \\
\text { Kualitas_Kehidupan_Kerja }\end{array}$} \\
\hline \multicolumn{6}{|l|}{$\begin{array}{l}\text { Kualitas_Kehidupan_Kerja - } \\
\text { > Kesetiaan }\end{array}$} \\
\hline $\begin{array}{l}\text { Pengembangan_Karier -> } \\
\text { Kesetiaan }\end{array}$ & 0.178 & 0.172 & 0.063 & 2.829 & 0.005 \\
\hline \multicolumn{6}{|l|}{$\begin{array}{l}\text { Pengembangan_Karier -> } \\
\text { Kinerja }\end{array}$} \\
\hline $\begin{array}{l}\text { Pengembangan_Karier -> } \\
\text { Kualitas_Kehidupan_Kerja }\end{array}$ & & & & & \\
\hline
\end{tabular}

Sumber : Hasil pengolahan data dengan SmartPLS V.3.2.1

Berdasarkan tabel indirect effect diatas dapat disimpulkan bahwa adanya hubungan tidak langsung antara dukungan sosial dengan kesetian, kompensasi dengan kesetiaan dan pengembangan karier dengan kesetian. Karena T-statistics pada hubungan tidak langsung tersebut lebih tinggi dibandingkan nilai $T$-table atau $\geq 1,96$ yang artinya terdapat pengaruh, meskipun secara tidak langung dibuat pada model penelitian ini.

\section{Pengaruh Kompensasi Terhadap Kualitas Kehidupan Kerja}

Hasil penelitian yang telah dilakukan mengenai pengaruh kompensasi terhadap kualitas kehidupan kerja membuktikan terdapat pengaruh positif dan signifikan dengan nilai $T$-statistic lebih dari 1,96 (3,876 > 1,96). Penelitian ini mendukung (Adhikari et al., 2012), yang menyatakan bahwa sifat ekstrinsik pekerjaan seperti upah dan gaji, insentif, fasilitas dan manfaat lainnya masih lebih penting untuk mempertahankan kualitas 


\section{National Conference of Creative Industry: \\ Sustainable Tourism Industry for Economic Development}

Universitas Bunda Mulia, Jakarta, 5-6 September 2018 e-ISSN No: 2622-7436

kehidupan kerja. Penelitian Lee et al. (2015; Jung et al, 2018) juga mendukung adanya hubungan antara atribut kualitas kehidupan kerja di antara karyawan, dan memberikan saran kepada praktisi untuk memperkuat kepuasan kerja karyawan, termasuk memprioritaskan beberapa atribut seperti upah yang adil.

\section{Pengaruh Kompensasi Terhadap Kinerja}

Hasil penelitian yang telah dilakukan mengenai pengaruh kompensasi terhadap kinerja membuktikan terdapat pengaruh positif dan signifikan dengan nilai $T$-statistic lebih dari 1,96 (4,615> 1,96). Penelitian ini mendukung (Türk, 2008), yang menjelaskan kompensasi berdasarkan output atau hasil merupakan pilihan yang lebih baik. Mayoritas peneliti mendukung kompensasi terkait hasil kerja, namun beberapa peneliti juga menaruh perhatian soal kaitan bagaimana cara mengukur produktivitas karyawan dan kerap kali hal tersebut menjadi pemicu kesalahan dalam sistem pengupahan berdasarkan kinerja (Türk, 2008).

\section{Pengaruh Pengembangan Karier Terhadap Kualitas Kehidupan Kerja}

Hasil penelitian yang telah dilakukan mengenai pengaruh pengembangan karier terhadap kualitas kehidupan kerja membuktikan terdapat pengaruh positif dan signifikan dengan nilai T-statistic lebih dari $1,96(2,034>1,96)$. Penelitian ini mendukung Li (2011) yang membahas mengenai kualitas kehidupan kerja dan perencanaan pengembangan karier, untuk mengetahui bagaimana persepsi karyawan terhadap pekerjaan mereka. Hal ini sejalan dengan penelitian Lee et al. (2015; Jung et al, 2018) untuk memprioritaskan atribut seperti pemberdayaan serta pelatihan yang efektif.

\section{Pengaruh Pengembangan Karier Terhadap Kinerja}

Hasil penelitian yang telah dilakukan mengenai pengaruh pengembangan karier terhadap kinerja membuktikan terdapat pengaruh positif dan signifikan dengan nilai $T$ statistic lebih dari 1,96 (3,092 > 1,96). Penelitian ini mendukung Bish (2004) diamana ditemukannya efek yang kuat bagi penerima aktivitas pengembangan, dimana peserta melaporkan tanggapan positif lebih banyak saat mereka menerima aktivitas pengembangan karier, dimana hal tersebut sering terlewat dari kinerja mereka sendiri.

\section{Pengaruh Dukungan Sosial Terhadap Kualitas Kehidupan Kerja}

Hasil penelitian yang telah dilakukan mengenai pengaruh dukungan sosial terhadap kualitas kehidupan kerja membuktikan terdapat pengaruh positif dan signifikan dengan nilai $T$-statistic lebih dari $1,96(2,868>1,96)$. Penelitian ini mendukung penelitian Ganesh (2014) yang menunjukkan bahwa dukungan atasan dan organisasi penting untuk menciptakan kualitas kehidupan kerja yang baik. Dukungan merupakan salah satu komponen kunci dari pengalaman kualitas kehidupan kerja yang baik, terdapat beberapa penelitian empiris yang secara langsung menghubungkan dukungan sosial dengan kualitas kehidupan kerja (Sirgy et al., 2001; Ganesh 2014).

\section{Pengaruh Dukungan Sosial Terhadap Kinerja}

Hasil penelitian yang telah dilakukan mengenai pengaruh dukungan sosial terhadap kinerja membuktikan terdapat pengaruh positif dan signifikan dengan nilai T-statistic lebih dari 1,96 (2,185 > 1,96). Penelitian ini mendukung Jyoti (2017; Lee 2010) yang mengungkapkan bahwa dukungan sosial meningkatkan efek kecerdasan pada penyesuaian. Oleh karena itu, dapat disimpulkan bahwa kecerdasan budaya, 


\section{National Conference of Creative Industry: \\ Sustainable Tourism Industry for Economic Development}

Universitas Bunda Mulia, Jakarta, 5-6 September 2018 e-ISSN No: 2622-7436

penyesuaian, pengalaman kerja di dan dukungan sosial (dari keluarga, teman, senior dan rekan kerja) memainkan peran penting dalam meningkatkan kinerja mereka (Jyoti 2017).

\section{Pengaruh Kualitas Kehidupan Kerja Terhadap Kesetiaan}

Hasil penelitian yang telah dilakukan mengenai pengaruh kualitas kehidupan kerja terhadap kesetiaan membuktikan terdapat pengaruh positif dan signifikan dengan nilai T-statistic lebih dari $1,96(4,159>1,96)$. Penelitian ini mendukung pernyataan Tiia (2017; Grote and Guest) dimana kualitas kehidupan kerja mempromosikan kesejahteraan dan otonomi pekerja. Karyawan yang bahagia adalah karyawan yang lebih produktif, berdedikasi dan setia (Greenhaus et al., 1987; Sirgy et al., 2001; Tiia 2017)

\section{Pengaruh Kinerja Terhadap Kesetiaan}

Hasil penelitian yang telah dilakukan mengenai pengaruh kinerja terhadap kesetiaan membuktikan terdapat pengaruh positif dan signifikan dengan nilai T-statistic lebih dari 1,96 (4,492 > 1,96). Penelitian ini mendukung Ibrahim (2012; Suliman dan Alkathairi, 2013) dimana peneliti dan praktisi, selama bertahun-tahun, meyakini bahwa karyawan yang berkomitmen untuk setia akan cenderung produktif, dengan kata lain kesetiaan dianggap sebagai motor penggerak di balik kinerja organisasi.

\section{KESIMPULAN DAN IMPLIKASI}

Berdasarkan penelitian yang telah dilakukan, maka dapat disimpulkan beberapa hal yaitu, kinerja berpengaruh positif dan signifikan terhadap kesetiaan generasi Y. Tenaga kerja generasi $\mathrm{Y}$ yang memberikan kinerja yang lebih baik dari perusahaan akan memiliki kesetiaan yang lebih baik pada perusahaan tersebut. Hasil penelitian juga menunjukkan kualitas kehidupan kerja berpengaruh positif dan signifikan. Tenaga kerja generasi $\mathrm{Y}$ yang memiliki kualitas kehidupan kerja yang lebih baik akan memiliki kesetiaan yang lebih baik pada perusahaan tersebut. Begitu juga dengan pengembangan karier berpengaruh positif dan signifikan terhadap kinerja dan kualitas kehidupan kerja generasi Y, dukungan sosial berpengaruh positif dan signifikan terhadap kinerja dan kualitas kehidupan kerja generasi Y dan kompensasi berpengaruh positif dan signifikan terhadap kinerja dan kualitas kehidupan kerja generasi Y. Tenaga kerja generasi Y pria ataupun wanita pada rentang usia 24-28 tahun (lahir pada tahun 1990-1994) cenderung lebih setia pada perusahaan mereka saat ini, dengan kecenderungan masa kerja antara 15 tahun, dengan catatan pernah pindah perusahaan kurang dari 2 kali selama masa karier mereka. Pada penelitian ini tidak ditemukannya pengaruh kesetiaan yang signifikan pada jender tertentu, namun adanya kecenderungan untuk lebih setia pada industri tertentu. Pada industri tertentu, tenaga kerja generasi Y mampu berkarier lebih lama dibandingkan pada industri lainnya, yaitu antara 10-15 tahun pada industri perdagangan besar / eceran (retail / wholesale) dan industri informasi, komunikasi \& teknologi.

Berdasarkan uraian yang telah disampaikan sebelumnya, penulis mencatat beberapa hal, untuk meningkatkan kesetiaan tenaga kerja generasi $\mathrm{Y}$, perusahaan perlu memperhatikan soal kompensasi yang diberikan, dukungan sosial ditempat kerja, pengembangan karier yang disediakan oleh perushaan, kualitas kehidupan kerja dan kinerja, agar generasi $\mathrm{Y}$ tersebut dapat meningkatkan kesetiaan mereka. Hal ini 


\section{National Conference of Creative Industry: \\ Sustainable Tourism Industry for Economic Development}

Universitas Bunda Mulia, Jakarta, 5-6 September 2018 e-ISSN No: 2622-7436

mendukung pernyataan Ibrahim (2014) bahwa kesetiaan juga dianggap sebagai kunci kualitas dan peningkatan produktivitas.

Peneliti sangat memahami bahwa penelitian ini masih jauh dari sempurna dan banyak keterbatasan yang belum terpenuhi dengan sampel sebanyak 120 responden. Oleh sebab itu diharapkan kritik dan saran agar penelitian ini lebih baik kedepannya. Terakhir penulis berharap penelitian ini dapat membantu menjawab persoalan dibidang sumber daya manusia, terutama yang berhubungan dengan generasi Y.

Untuk penelitian selanjutnya diharapkan dapat mengambil sampel yang lebih banyak lagi, serta meneliti pengaruh jender lebih dalam pada generasi Y. Menurut Clarke (2015) tren demografi baru-baru ini di negara-negara industri telah menghasilkan rumah tangga berpenghasilan ganda yang menggantikan model laki-laki tradisional sebagai pencari nafkah. Mungkin hal tersebut dapat dipertimbangkan untuk melihat apakah adanya kesetiaan kerja pada pasangan generasi $\mathrm{Y}$ yang sudah berkeluarga dengan anak atau tanpa anak.

\section{DAFTAR PUSTAKA}

Buku

Jogiyanto, H.M. dan Willy Abdillah, 2016. Konsep Dan Aplikasi PLS (Partial Least Square) Untuk Penelitian Empiris. BPFE, Yogyakarta.

\section{Artikel dalam Jurnal Publikasi}

Adelle J. Bish Lisa M. Bradley Leisa D. Sargent, 2004 "Career development for going beyond the call of duty: is it perceived as fair?", Career Development International, Vol. 9, Issue 4: 391 - 405

Ainsworth Anthony Bailey Faisal Albassami Soad Al-Meshal, 2016,"The roles of employee job satisfaction and organizational commitment in the internal marketing-employee bank identification relationship", International Journal of Bank Marketing, Vol. 34, Issue 6: 821 - 840

Alexander Bruggen, 2015 "An empirical investigation of the relationship between workload and performance" Management Decision, Vol. 53, Issue 10:

Chaur-Luh Tsai, Yan-Wei Liou, 2017 "Determinants of work performance of seafarers", Maritime Business Review, Vol. 2, Issue 1:36-51

Cheng-Liang Yang, Mark Hwang, 2014 "Personality traits and simultaneous reciprocal influences between job performance and job satisfaction", Chinese Management Studies, Vol. 8, Issue 1: 6-26

Christin Moeller Greg A. Chung-Yan, 2013 "Effects of social support on professors' work stress", International Journal of Educational Management, Vol. 27, Issue 3: $188-202$

Decha Dechawatanapaisal, "The mediating role of organizational embeddedness on the relationship between quality of work life and turnover: Perspectives from healthcare professionals", International Journal of Manpower

Denis Chênevert, Michel Tremblay, 2011 "Between universality and contingency: An international study of compensation performance", International Journal of Manpower, Vol. 32, Issue 8: 856-878 


\section{National Conference of Creative Industry: \\ Sustainable Tourism Industry for Economic Development}

Universitas Bunda Mulia, Jakarta, 5-6 September 2018 e-ISSN No: 2622-7436

Dev Raj Adhikari, Katsuhiko Hirasawa, Yutaka Takakubo, Dhruba Lal Pandey, 2011 "Decent work and work life quality in Nepal: an observation", Employee Relations, Vol. 34, Issue 1: 61-79

Guido Alessandri, Chiara Consiglio, Fred Luthans, Laura Borgogni, 2018 "Testing a dynamic model of the impact of psychological capital on work engagement and job performance", Career Development International

Guiyao Tang, Bingjie Yu, Fang Lee Cooke, Yang Chen, 2017 "High-performance work system and employee creativity: The roles of perceived organisational support and devolved management" Personnel Review, Vol. 46, Issue 7:1318-1334

Hakan Oktal Kadriye Yaman, 2011 "A new approach to air traffic controller workload measurement and modelling", Aircraft Engineering and Aerospace Technology, Vol. 83, Issue 1: $35-42$

Hee Jung (Annette) Kang, James Busser, Hyung-Min Choi, 2018 "Service climate: how does it affect turnover intention?", International Journal of Contemporary Hospitality Management, Vol. 30, Issue 1 : 76-94

Hong T.M. Bui, Yolanda Zeng, Malcolm Higgs, 2017 "The role of person-job fit in the relationship between transformational leadership and job engagement", Journal of Managerial Psychology

Jeevan Jyoti, Sumeet Kour, 2017 "Factors affecting cultural intelligence and its impact on job performance: role of cross-cultural adjustment, experience and perceived social support", Personnel Review, Vol. 46, Issue: 4

Jessica Li Roland K. Yeo, 2011 "Quality of work life and career development: perceptions of part-time MBA students", Employee Relations, Vol. 33 Issue 3: 201 $-220$

Johanim Johari, Fee Yean Tan, Zati Iwani Tjik@Zulkarnain, 2006 "Autonomy, workload, work life balance and job performance teachers", International Journal of Educational Management

John G. Cullen, 2013 "Vocational ideation and management career development", Journal of Management Development, Vol. 32, Issue 9: 932 - 944Jin-Soo Lee KiJoon Back Eric S.W. Chan, 2015 "Quality of work life and job satisfaction among frontline hotel employees: a self-determination and need satisfaction theory approach", International Journal of Contemporary Hospitality Management, Vol. 27, Issue 5:

Josée Bloemer Gaby Odekerken-Schröder, 2006 "The role of employee relationship proneness in creating employee loyalty" International Journal of Bank Marketing, Vol. 24, Issue 4:252-264

Ka Wai Chan \& Thomas A. Wyatt, 2007 "Quality Of Work Life: A Study of Employees in Shanghai, China" Asia Pacific Business Review, Vol. 13, No.4:501-517

Kulno Türk, 2008"Performance appraisal and the compensation of academic staff in the University of Tartu", Baltic Journal of Management, Vol. 3, Issue 1: 40 - 54

Laura M. Crothers Ara J. Schmitt Tammy L. Hughes John Lipinski Lea A. Theodore Kisha Radliff Sandra Ward, 2010,"Gender differences in salary in a femaledominated profession", Gender in Management: An International Journal, Vol. 25, Issue 7: 605 - 626

Lisa A. Burke, Chengho Hsieh, 2006 "Optimizing fixed and variable compensation costs for employee productivity", International Journal of Productivity and Performance Management, Vol. 55, Issue 2: 155-162 


\section{National Conference of Creative Industry: \\ Sustainable Tourism Industry for Economic Development}

Universitas Bunda Mulia, Jakarta, 5-6 September 2018 e-ISSN No: 2622-7436

Maha Ibrahim Saoud Al Falasi, 2014 "Employee loyalty and engagement in UAE public sector", Employee Relations, Vol. 36, Issue 5: 562-582

Mansi Rastogi, Santosh Rangnekar, Renu Rastogi, 2017 "Psychometric evaluation of need-based quality of work life scale in an Indian sample", Industrial and Commercial Training

Marc van Veldhoven and Luc Dorenbosch, 2008 "Age, proactivity and career development", Career Development International, Vol. 13, Issue 2: 112-131

Maria Tims, Arnold B. Bakker dan Daantje Derks, 2014 "Daily job crafting and the self-efficacy-performance relationship", Journal of Managerial Psychology, Vol. 29, Issue 5: 490 - 507

Marilyn Clarke, 2015 "Dual careers: the new norm for Gen Y professionals?", Career Development International, Vol. 20, Issue 6: 562 - 582

Md. Abu Taher, 2013 "Variations of quality of work life of academic professionals in Bangladesh", European Journal of Training and Development, Vol. 37, Issue 6: $580-595$

Mohit Yadav dan Mohammad Faraz Naim, 2017 "Searching for Quality in Quality of work life: An Indian power sector perspective", Industrial and Commercial Training, Vol. 49, Issue 4

Nada Al Mehrzi Sanjay Kumar Singh, 2016 "Competing through employee engagement: a proposed framework", International Journal of Productivity and Performance Management, Vol. 65, Issue 6

Nguyen Dinh Tho Nguyen Dong Phong Tran Ha Minh Quan, 2014 "Marketers' psychological capital and performance", Asia-Pacific Journal of Business Administration, Vol. 6, Issue 1: $36-48$

Noko Seopa, Albert Wöcke, Camilla Leeds, 2015 "The impact on the psychological contract of differentiating employees into talent pools", Career Development International, Vol. 20, Issue 7 : 717-732

Olivia Guillon Cécile Cezanne, 2014 "Employee loyalty and organizational performance: a critical survey", Journal of Organizational Change Management, Vol. 27, Issue 5: $839-850$

Paul D. Larson and Matthew Morris, 2014 "Sex and salary", Supply Chain Management: An International Journal, Vol. 19, Issue 4 : 385 - 394

Sheena Fatima Paro Ragas, Flora Mae Angub Tantay, Lorraine Joyce Co Chua, Carolyn Marie Concha Sunio, 2017 "Green lifestyle moderates GHRM's impact to job performance", International Journal of Productivity and PerformanceManagement

Rita Fontinha, Darren Van Laar \& Simon Easton, 2016 "Quality of working life of academics and researchers in the UK: the roles of contract type, tenure and university ranking, Studies in Higher Education

Roland K. Yeo Jessica Li, 2013 "In pursuit of learning: sensemaking the quality of work life", European Journal of Training and Development, Vol. 37, Issue 2: 136 - 160

Sunyoung Park, Hye-Seung (Theresa) Kang, Eun-Jee Kim, 2017 "Does supervisor support make a difference in employees' training and job performance? An empirical study of a professional development program", European Journal of Training and Development

Suman Basuroy Kimberly C. Gleason Yezen H. Kannan, 2014 "CEO compensation, customer satisfaction, and firm value", Review of Accounting and Finance, Vol. 13, Issue 4: 326 - 352 


\section{National Conference of Creative Industry: \\ Sustainable Tourism Industry for Economic Development}

Universitas Bunda Mulia, Jakarta, 5-6 September 2018 e-ISSN No: 2622-7436

Sarlaksha Ganesh Mangadu Paramasivam Ganesh, 2014 "Effects of masculinityfemininity on quality of work life", Gender in Management: An International Journal, Vol. 29, Issue 4:229-253

Soumendu Biswas Arup Varma, 2011"Antecedents of employee performance: an empirical investigation in India", Employee Relations, Vol. 34, Issue 2: 177 - 192

Susan Linz Linda K Good Michael Busch, 2015 "Promoting worker loyalty: an empirical analysis", International Journal of Manpower, Vol. 36, Issue 2: 169 191

Sylvie Guerrero Hélène Jeanblanc Marisol Veilleux, 2016 "Development idiosyncratic deals and career success", Career Development International, Vol. 21, Issue 1: 9 $-30$

Tiia Annika Wahlberg, Nelson Ramalho, Ana Brochado, 2017 "Quality of working life and engagement in hostels", Tourism Review

\section{Sumber Elektronik/Internet}

Ibrahim, 2017. Mengapa Gen Y Tak Setia pada Tempatnya Bekerja? Diakses pada 11 April 2018, dari https://technobusiness.id/2017/02/16/news-update/and-othersnews-update/mengapa-gen-y-tak-setia-pada-tempatnya-bekerja/ 